\title{
Tax Effort and Determinants of Tax Ratios in Kenya
}

\author{
James Murunga, MA \\ Moses Muriithi, PhD \\ Joy Kiiru, PhD
}

University of Nairobi, School of Economics, Kenya

\begin{abstract}
Doi: 10.19044/elp.v3no2a2 URL:http://dx.doi.org/10.19044/elp.v3no2a2
\end{abstract}
\begin{abstract}
The study analyzes the tax effort and the factors which influence tax ratios in Kenya. Tax revenue collected from 1980 to 2015 has been less than the government expenditure forcing the government to borrow from domestic banks and foreign financial institutions. Identification of the factors that influence tax ratio to GDP in Kenya is important as it will inform policy regarding the taxation system. Many studies have investigated the determinants of the tax ratio to GDP and tax effort indices using majorly panel data research method on developing and developed countries, but a few have been conducted in Kenya. This study sought to add to the literature and and carried out an in-depth investigation of tax ratio to GDP and tax effort in Kenya by taking into account relevant explanatory variables and time series research methodology. To achieve study objective, time series data running from 1980 to 2015 was analyzed by use of ordinary least squares regression. The explanatory variables considered in the study were per capita GDP, share of service sector in GDP, share of external debt in GDP, share of agriculture in GDP, share of exports in GDP and share of imports in GDP. The findings revealed that the coefficients of per capita GDP, share of service sector in GDP and share of agriculture in GDP to be positive but significant. On the other hand the coefficients of the share of external debt in GDP and share of export in GDP were negative but insignificant. The coefficient of the share of import in GDP was positive but insignificant. The study further found Kenya's tax effort to be less than unity meaning the country is not utilizing its tax capacity fully. This therefore implies that the country has potential of raising more tax to reduce the imbalance in its budget. The study recommends the need for political will, efficient legal system and consistency in the implementation of tax policy. Achievement of this will attract investment that will lead to increased per capita income and job opportunities which eventually translate to increased
\end{abstract}


taxes.

Keywords: Tax effort, ratio, Kenya

\section{Introduction:}

Kenya's economy has remained resilient and has registered a relatively strong economic growth amidst the world economic slowdown. This remarkable growth is attributed to the ongoing investment in infrastructure, improvement in agricultural output, consumer confidence and investor confidence. In 2015, the country registered an economic growth of 5.6 percent which was above the Sub-Saharan region average growth of 3.5 percent. However, despite this impressive growth, Kenya's budget deficit stands at 9.2 percent of GDP which is much above the internationally acceptable level of 4 percent of GDP. This increase in budget deficit is attributed to increased expenditure on internal security, infrastructure and debt servicing (National Treasury, 2016).

The continued increase in the Kenya's budget deficit indicates that the country's tax system is not doing well in terms of revenue production. According to Wilford \& Wilford (1978), emerging economies ought to increase their tax mobilization in order to realize economic growth. The most important tool to achieve this is the adoption of an effective tax policy.

Kenya has witnessed an increase in its tax revenue from 14187 million shillings in 1980 to 1288870.13 million shillings in 2015 (KNBS, 2015). The increase in revenue is attributed to implementation of various tax reforms that took place from early 1970s. For instance, in 1973 there was shift of tax burden to consumer through the introduction of sales tax. The sales tax was later replaced with value added tax (VAT) in 1990. VAT was seen to be much effective than sales tax due to its wide coverage and flexibility. The other tax reforms that were implemented include the revision of tariffs and tax rates, expansion of tax base (Wawire, 2000). According to Cheeseman \& Griffiths (2005), establishment of KRA in 1995 also contributed to the increase in tax revenue as a result of improved tax administration and efficient implementation of organizational reforms.

The income tax structure in Kenya has also undergone various reforms. These reforms include the removal of double taxation where investors income was taxed at corporate level and individual level. The Kenyan tax system has also introduced personal identification number (PIN) to help in the assessment of for purposes of tax compliance. The PIN was introduced with an objective of improving tax information. The PIN helps Kenya Revenue Authority to identify all transactions made by all taxable citizens in the country hence capturing the appropriate tax (Muriithi \& Moyi, 2003). 
Tax capacity is the maximum tax which a country can raise given its economic, institutional, social and demographic arrangement (Pessino and Fenochietto, 2010). Tax ratio shows how tax is performing in terms of using the taxable capacity at a particular time (Islam, 1979).

The Kenyan tax system is mainly a two tier system. It is based on the central government and the county governments. The Kenyan constitution empowers the government to levy tax on given individuals and organizations. Article 209 of the Kenyan constitution, distributes legislative authority which includes taxation between the national assembly and the county parliaments (Constitution of Kenya, 2010)

\section{Problem Statement}

Kenya has adopted various tax reforms since 1980 but country's expenditure has remained higher than its revenue. Figure 1 below shows the trends in Kenya's fiscal expenditure and revenue. The vertical axis shows total tax revenue and total expenditure in millions Kenyan shillings (KES M). The horizontal axis shows the years running from 1980 to 2015.

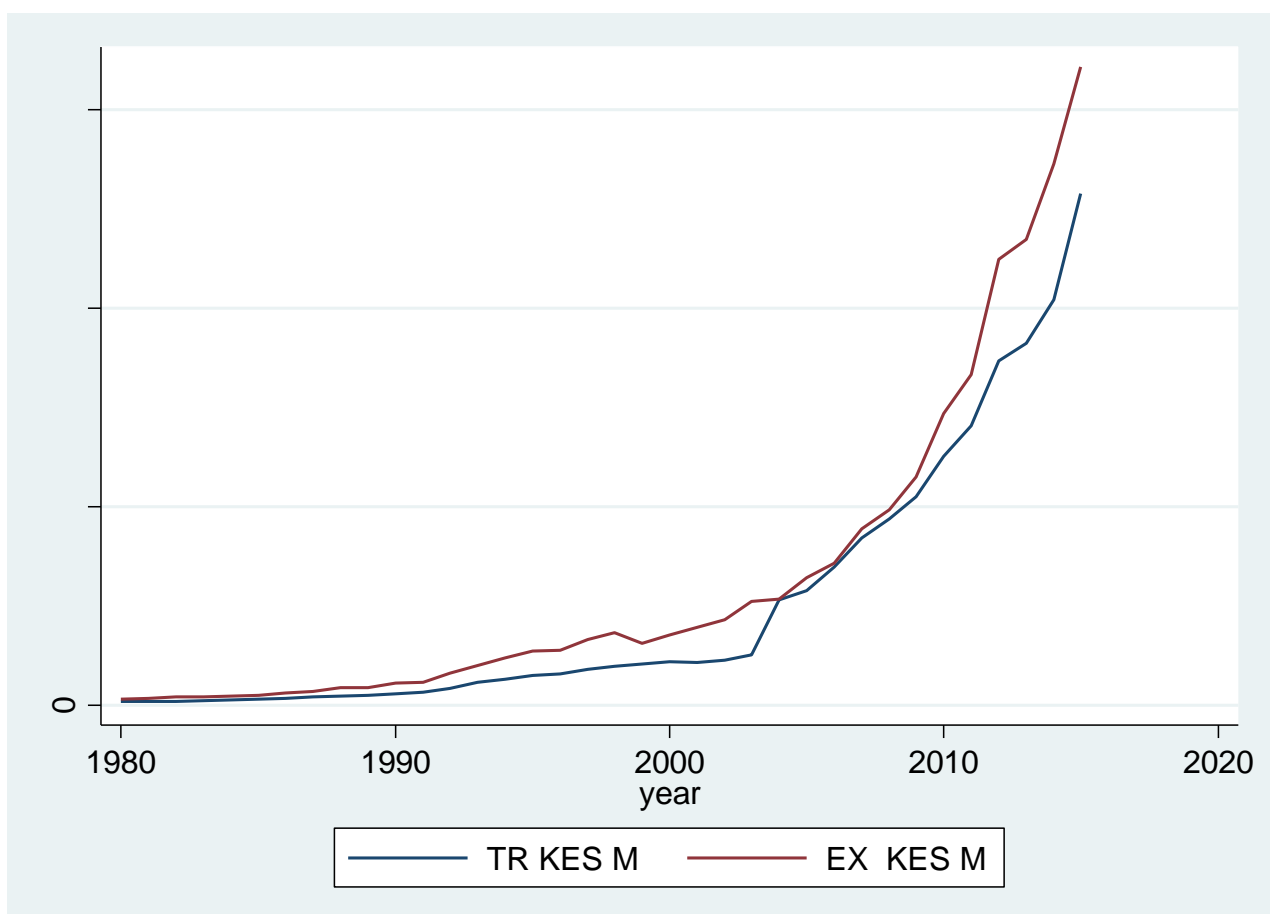

Figure 1: Kenya's Fiscal Operation 
From figure 1, it is evident that revenue collected from 1980 to 2015 has been less than the government expenditure indicating that the government was not able to meet its obligation of providing public goods and services using its own resources. The inability to raise the required revenue made the government to incur large deficits in the overall government budget forcing it to borrow from domestic banks and foreign financial institutions. Since borrowing has serious ramifications in the medium and long run, the government must ensure strong tax ratio to GDP enable it generate adequate tax revenue.

Many studies have investigated the determinants of the tax ratio to GDP and tax effort indices using majorly panel data research method, but a few have been conducted in Kenya. For instance, Wawire (2000) investigated tax effort indices for Kenya using aggregated data. The findings showed that Kenya's tax system had failed to mobilize necessary revenues. Current study bridges the gap in the literature and seeks to carry out an indepth investigation of tax ratio to GDP and tax effort in Kenya by taking into account relevant explanatory variables and time series research methodology. Based on this, the paper therefore seeks to respond to the following questions;

- What are the factors influencing tax ratio to GDP in Kenya?

- What is the trend of tax effort indices in Kenya from 1980 to 2015?

- Do the trends indicate over-taxation of the economic agents?

- What policy recommendations can be drawn from the study findings?

\section{Objective of the Study}

The objective of this study is to determine the factors that influence tax ratio to GDP in Kenya and also identify the trend of tax effort indices in Kenya from 1980 to 2015.

\section{Literature Review}

Lutfunnahar (2007) investigated the determinants of the share of tax revenue in GDP for Bangladesh and other 10 developing countries using panel research methodology. The study showed that share of broad money in GDP, share of international trade in GDP, share of external debt in GDP are significant determinants of the share of tax revenue in GDP. The study made a conclusion that Bangladesh and other 10 developing countries were not making maximum use of their capacity in raising tax revenue. This was because the study obtained tax effort indices of less than unity an implication that these countries had the potential of mobilizing more tax revenue to finance their budgets.

Mahdavi (2008) investigated the determinants of share of tax revenue in GDP for 43 developing countries using panel research methodology. The 
study findings showed that share of trade sector in GDP and share of agriculture in GDP positively influence share of tax revenue in GDP.

Ahsan and $\mathrm{Wu}$ (2005) investigated the determinants of the share of tax revenue in GDP for developing and developed countries using panel research method. The study findings showed that the coefficients of population growth rate, share of agriculture in GDP and per capita GDP share of trade sector in GDP were positive and significant. On the other hand the coefficient of the share of trade sector in GDP was positive and significant. The coefficient of corruption was negative but insignificant.

Alm et al. (2004) studied determinants of the share of tax revenue in GDP for developed and developing countries using panel research methodology. The study findings showed that the coefficient of the share of mining in GDP was positive and significant. On the other hand, the coefficient of per capita GDP was negative but significant. The coefficients of the share of agriculture in GDP and share of international trade in GDP were negative but insignificant.

Stotsky and WoldeMariam (1997) and Leuhold (1991) investigated determinants of the share of tax revenue in GDP for African countries using panel research methodology. The results showed that the share of agriculture in GDP negatively influence the share of tax revenue in GDP. On the other hand, the share of mining in GDP and share of foreign trade in GDP and share of foreign grants and loans in GDP positively influence the share of tax revenue in GDP.

Pessino and Fenochietto (2013) studied the determinants of tax effort for 113 countries using panel regression model. Their findings showed that level of development measured by per capita GNP, share of exports and imports in GNP positively affect tax effort. On the hand, corruption and Gini coefficient which is used to measure the extent inequality negatively affect the tax ratio.

Botlhole (2010) studied the determinants of countries' tax effort in Sub-Saharan Africa using panel research method. The study findings indicated that resource incomes and corruption are important determinants of tax effort.

Islam (1979) investigated the factors that influence tax effort in Bangladesh using ordinary least square regression model. The author found that share of agriculture in GDP, per capita GNP and share of expenditure on tax collection in GDP influence tax effort. However, the coefficient of the share of imports and exports in GDP was seen to be the most significant.

Gupta (2007) investigated the major factors that explain why there is variation in tax revenue supply among the developing economies using panel research method. In his findings, coefficients of country's openness, share of 
agriculture in GDP, per capita GDP, corruption and political stability were observed to be statistically significant.

Tanzi (1992) studied the relationship between tax revenue and structural factors among the developing countries using panel research method. The study findings showed that the share of import in GDP, per capita GDP, share of agriculture in GDP and share of foreign debt in GDP were determinants of the share of tax revenue in GDP.

Teera (2002) studied the factors that influence share of tax revenue in GDP in Uganda using time series data running from 1970 to 2000. In his findings, coefficients of tax evasion, economic development, openness index of the economy, fiscal deficits and share of manufacturing in GDP were statistically significant.

From the reviewed literature, the factors that influence tax revenue in GDP are;

- National income,

- opennnes to trade,

- manufacturing share in GDP,

- budget deficit,

- import share in GDP,

- export share in GDP,

- external debt share in GDP,

- corruption,

- Gini coefficient,

- agriculture share in GDP,

- industry share in GDP,

- political stability,

- tax evasion

\section{Methodology and Estimation}

\section{Theoretical Framework}

An approach to measuring taxable capacity is regressing tax to GDP ratio of a particular country on varoius tax handles as the explanatory variables. These explanatory variables are used as proxies for probable tax bases and any other factors which may influence a country's ability to mobilise tax revenues. This approach has been used by various scholars for instance Lotz \& Morss (1967), Tanzi (1992) and Chelliah (1971). The predicted tax ratio to GDP from this approach shows the taxable capacity while the coefficients of the regression are considered as the average effective rates on the given tax bases. Equation 1 shows the general form equation for estimating taxable capacity.

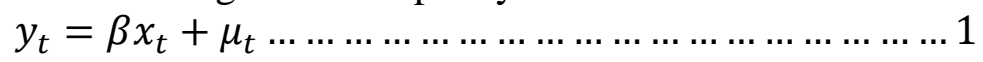


Where $y_{t}$ shows tax revenue ratio to GDP at time $\mathrm{t}, \quad x_{t}$ is a vector of tax handles at time $\mathrm{t}, \beta$ is a vector of coefficients of the variables that are expected to influence tax revenue to GDP ratio and $\mu_{t}$ is an arror term at time $t$ satisfying the usual OLS assumptions.

\section{Empirical Model}

The theoretical framework translates into an operational estimation framework by incorporating explanatory variables as suggested by the reviewed literature as shown.

$$
\begin{gathered}
\operatorname{tax}=\beta_{0}+\beta_{1} p g d p+\beta_{2} \text { service }+\beta_{3} \text { debt }+\beta_{4} \text { agric }+\beta_{5} \text { exports } \\
+\beta_{6} \text { import }+\mu \ldots 2
\end{gathered}
$$

Where, tax is tax ratio to GDP, $p g d p$ is per capita GDP, service is share of service sector in GDP, debt is share of external debt in GDP, agric is share of agriculture in GDP, exports is share of exports in GDP, import is share of imports in GDP. The coefficients $\beta_{0}, \beta_{1}, \beta_{2}, \beta_{3}, \beta_{4}, \beta_{5}$ and $\beta_{6}$ are parameters to be estimated while $\mu$ is the error term with usual OLS assumptions.

\section{Results}

The data used in the study was obtained from World Bank world development indicators.

\section{Descriptive Statistics}

Summary statistics of tax revenue ratio in GDP and the expanatory variables are as shown in table 1.

Table 1: Summary Statistics

\begin{tabular}{|l|l|l|l|l|l|}
\hline Variable & Observation & Mean & $\begin{array}{l}\text { Standard } \\
\text { Deviation }\end{array}$ & Minimum & Maximum \\
\hline tax & 36 & 16.404 & 3.672037 & 5 & 20.494 \\
\hline pgdp & 36 & 70605.54 & 6058.73 & 64898.74 & 87965.72 \\
\hline service & 36 & 50.83125 & 2.398367 & 46.4088 & 54.96807 \\
\hline debt & 36 & 53.78391 & 26.63139 & 21.24461 & 131.8993 \\
\hline Agric & 36 & 30.13855 & 2.791013 & 23.15672 & 34.21953 \\
\hline exports & 36 & 24.52185 & 4.933735 & 15.76902 & 38.90363 \\
\hline import & 36 & 31.86646 & 3.10595 & 26.39755 & 39.15404 \\
\hline
\end{tabular}

Table 1 shows that the total observations considered in this study were 36 with seven variables (one dependent and six independent variables). Range is obtained from the difference between the maximum value and minimum value. For example the maximum value of service share in GDP is $54.96807 \%$ while the minimum is $46.4088 \%$ giving a range of $8.55927 \%$. The standard deviation shows the spread of the values from the mean and is 
important for comparison purposes. The data shows that per capita GDP has a larger spread as compared to other variables. The share of service in GDP has a standard deviation of 26.63139 , debt has 26.63139 , agriculture has 2.791013, exports has 4.933735 and imports has 3.10595 .

\section{Stationarity Check}

The Augmented Dickey Fuller test was used to test for stationarity of the variables. The test results are as shown in Table 2.

Table 2: Test for Stationarity in Levels

\begin{tabular}{|l|l|l|l|l|}
\hline Variables & Test statistic & $1 \%$ critical level & $5 \%$ critical level & $\begin{array}{l}10 \% \text { critical } \\
\text { level }\end{array}$ \\
\hline tax & -2.356 & -3.682 & -2.972 & -2.618 \\
\hline pgdp & 2.125 & -3.682 & -2.972 & -2.618 \\
\hline service & -1.799 & -3.682 & -2.972 & -2.618 \\
\hline debt & -1.110 & -3.682 & -2.972 & -2.618 \\
\hline agric & -1.484 & -3.682 & -2.972 & -2.618 \\
\hline exports & -1.754 & -3.682 & -2.972 & -2.618 \\
\hline import & -3.716 & -3.682 & -2.618 & -2.618 \\
\hline
\end{tabular}

Table 2 shows that all the variables had at least a unit root at levels except the share of import in GDP. All the variables that were non stationary were differenced and the results are as shown in the Table 3.

Table 3: Test for Stationarity (First Difference)

\begin{tabular}{|l|l|l|l|l|}
\hline Variables & Test statistic & $1 \%$ critical level & $5 \%$ critical level & $\begin{array}{l}10 \% \text { critical } \\
\text { level }\end{array}$ \\
\hline D1 tax & -5.115 & -3.689 & -2.975 & -2.619 \\
\hline D1 service & -5.614 & -3.689 & -2.975 & -2.619 \\
\hline D1debt & -5.925 & -3.689 & -2.975 & -2.619 \\
\hline D1agric & -3.782 & -3.689 & -2.975 & -2.619 \\
\hline D1exports & -5.341 & -3.689 & -2.975 & -2.619 \\
\hline D1pgdp & -6.550 & -3.696 & -2.978 & -2.620 \\
\hline
\end{tabular}

Table 3 shows that all the variables became stationary after first difference. The data was further subjected to other diagnostic tests. Heteroscedasticity and serial correlation which were detected and corrected through robust regression. Based on the unit root test result, cointegration test was not necessary. This is because the variables were integrated of different orders.

\section{Estimation Results}

To establish the determinants of tax ratio to GDP, the study conducted linear regression model as indicated in Table 4. 
Table 4: Regression Results

\begin{tabular}{|c|c|c|c|c|}
\hline $\begin{array}{l}\text { Dependent Va } \\
\text { Method: } \\
\text { Sample: }\end{array}$ & $\begin{array}{l}\text { le: D1tax } \\
\text { OLS } \\
35 \\
\end{array}$ & & & \\
\hline $\begin{array}{l}\text { Sample: } \\
\text { Variable }\end{array}$ & Coefficient & Standard error & t-statistic & Prob \\
\hline Constant & 4.876608 & 4.958934 & 0.98 & 0.334 \\
\hline D1pgdp & 0.0005716 & 0.0002568 & 2.23 & $0.034 * *$ \\
\hline D1service & 1.91218 & 0.5304933 & 3.60 & $0.001 * * *$ \\
\hline D1debt & -0.1089213 & 0.0701105 & -1.55 & 0.132 \\
\hline D1agric & 1.336064 & 0.4485293 & 2.98 & $0.006^{* * *}$ \\
\hline D1exports & 0.1801705 & 0.2393999 & 0.75 & 0.458 \\
\hline imports & -0.1575857 & 0.1547142 & -1.02 & 0.317 \\
\hline $\mathrm{R}^{2}$ & 0.3130 & & & \\
\hline F statistic & 0.0023 & & & \\
\hline \multicolumn{5}{|c|}{$\begin{array}{lll}\text { Normality- Shapiro wilk } & 0.97950(0.72859)\end{array}$} \\
\hline \multirow{2}{*}{\multicolumn{3}{|c|}{$\begin{array}{l}\text { Heteroscedasticity - Breusch-pagan-Godfrey } \\
\text { Autocorrelation - Breusch-Godfrey }\end{array}$}} & \multicolumn{2}{|c|}{$(0.0000)$} \\
\hline & & & 11.801 & \\
\hline \multicolumn{3}{|c|}{ Stability Ramsey Reset } & 6.46 & \\
\hline
\end{tabular}

Where $* * *, * *$ indicates significance at $1 \%$ and $5 \%$ levels respectively.

The regression performed well in terms of overall significance since the $\mathrm{F}$ statistic is significant at $5 \%$ level. This implies that variables in the model were jointly significant in explaining tax ratio to GDP. Further, the results showed an R-squared of $31.3 \%$ an implication that $31.3 \%$ of variability in determining tax ratio to GDP. Diagnostic tests were conducted and indicated that the errors were normally distributed. The Ramsey Reset test showed omission of the variables in the model. This is true since there are more other variables which explain tax ratio to GDP as reviewed in the literature. They may not have been considered due to lack of data. However, their effect was captured in the stochastic model used.

\section{Discussion of Results}

The results indicate that per capita GDP, share of service sector in GDP, share of agriculture in GDP and export share in GDP positively affect tax ratio to GDP. Share of external debt in GDP and share of imports in GDP negatively affect tax ratio to GDP. The results further shows that per capita GDP, share of service in GDP and share of agriculture in GDP as important determinants of tax ratio to GDP.

The coefficient of per capita GDP is positive and statistically significant. Kenya's per capita GDP has been increasing since 1980 to 2015. The increase in per capita GDP depicts increased economic activities which translates into increased capacity to pay and mobilise taxes. These findings are in line with earlier study by Ahsan and Wu (2005) who found per capita GDP to be positive and important in determining tax ratio to GDP. 
The coefficient of service sector in GDP is positive and significant. This is contrary to many earlier researchers who show that most of the service sector in developing countries is practised in the informal sector making it difficult to tax it. These findings are however, in line with earlier study by Chaudhry and Munir (2010).

The coefficient of share of agriculture in GDP is positive and statistically significant which is contrary to economic theory. According to economic theory, agriculture is a difficult sector to tax in developing country like Kenya since most lands are communally owned. However, its positive contribution to Kenya's tax revenue is due to the heavy indirect taxation of the sector through overvaluation of the exchange rates, import quotas and tariffs.These findings are in line with earlier study by Mahdavi (2008). However,the results contradicts earlier studies by Leuhold (1991) and Stotsky and WoldeMariam (1997) who found share of agriculture in GDP to negatively influence tax ratio to GDP.

\section{Kenya's Tax Effort}

To obtain Kenya's tax effort indices, the study used estimates obtained in Table 4 to obtain predicted tax ratio to GDP for each year under the study. Tax effort index for each year was eventually obtained by dividing actual tax ratio to GDP by the predicted tax ratio to GDP. The results are shown in table 5 .

Table 5: Tax Effort Indices

\begin{tabular}{|l|l|l|l|}
\hline Year & $\begin{array}{l}\text { Tax } \\
\text { Efforts } \\
\text { Indices }\end{array}$ & Year & $\begin{array}{l}\text { Tax } \\
\text { Efforts } \\
\text { Indices }\end{array}$ \\
\hline 1980 & 0.294 & 1998 & 0.394 \\
\hline 1981 & 0.367 & 1999 & 0.423 \\
\hline 1982 & 0.383 & 2000 & 0.449 \\
\hline 1983 & 0.404 & 2001 & 0.471 \\
\hline 1984 & 0.371 & 2002 & 0.466 \\
\hline 1985 & 0.145 & 2003 & 0.423 \\
\hline 1986 & 0.130 & 2004 & 0.445 \\
\hline 1987 & 0.264 & 2005 & 0.474 \\
\hline 1988 & 0.371 & 2006 & 0.426 \\
\hline 1989 & 0.499 & 2007 & 0.419 \\
\hline 1990 & 0.483 & 2008 & 0.454 \\
\hline 1991 & 0.436 & 2009 & 0.452 \\
\hline 1992 & 0.474 & 2010 & 0.444 \\
\hline 1993 & 0.396 & 2011 & 0.438 \\
\hline 1994 & 0.397 & 2012 & 0.425 \\
\hline 1995 & 0.537 & 2013 & 0.414 \\
\hline 1996 & 0.409 & 2014 & 0.404 \\
\hline 1997 & 0.423 & 2015 & 0.396 \\
\hline
\end{tabular}


The results indicate that minimum tax effort index was 0.130 for the year 1986 whereas the maximum was 0.537 for the year 1995 . All the period under study had indices less than unity an implication that there was under taxation. For instance, in 1995 there was under-taxation of about 46 percent. The average tax effort index was 0.417 , which shows under taxation of 58.3 percent.

\section{Conclusion and Recommendations}

For Kenya to be self-sufficient, adequate tax revenue should be raised. This study has made an attempt of identifying the determinants of tax ratio to GDP and tax effort in Kenya using time series data running from 1980 to 2015.

The variables considered in the econometric analysis include per capita GDP, share of service sector in GDP, share of external debt in GDP, share of agriculture in GDP, share of exports in GDP and share of imports in GDP.

The findings obtained show that the coefficients of per capita GDP, share of service sector in GDP and share of agriculture in GDP are positive and significant. On the other hand, coefficient of the share of external debt in GDP, share of import in GDP are negative but insignificant.The coefficient of the share of export in GDP is positive but insignificant. The sign of the per capita GDP is line with the expectation but that of the share of agriculture and service sector share in GDP deviates form the expectation.

Further, tax effort indices for Kenya shows that there was under taxation during the study period. This is because the tax effort indices are less than unity. This clearly shows that Kenya is not making maximum use of its tax capapcity. This therefore implies that the country has the potential to mobilise more tax revenue and reduce its budget imbalances.

The results indicate that the determinants of low tax ratio to GDP in Kenya is due to much reliance on the agricultural and service sector as sources of tax revenue. It is an uphill task for Kenyan government to come up with a suitable tax design that will get maximum tax revenue from these sectors. This is because most of the agricultural sector and service sector in Kenya is practised informally. A large proportion of Kenya's service sector is made up of small businesses making it difficult to bring them into the tax net.

High per capita GDP has the potential of realizing higher tax revenues. This is becasue high per capita income implies country's population purchasing power is increased making them to pay tax with ease. To ensure increase in per capita income, there is need for political will, efficient legal system and consistency in the implimentation of tax policy. If this is achieved then country will attract investment that will lead to job opportunities which eventually translates into increased taxes. 


\section{References:}

Ahsan, S.M. and Wu, S. (2005). Tax Structure and Reform in China, 19792002. Mimeo Department of Economics, Concordia University, Canada.

Botlhole, T. D. (2010). Tax effort and the determinants of tax ratio in SubSahara Africa. In International Conference On Applied Economics-ICOAE. Chaudhry, I.S. and Munir, F. (2010). Determinants of Low Tax Revenue in Pakistan. Pakistan Journal of Social Sciences (PJSS), Vol. 30, No. 2, pp. 439-452

Cheeseman, N., \& Griffiths, R. (2005). Increasing tax revenue in subSaharan Africa: The case of Kenya. OCGG Economy Analysis, (6).

Chelliah, R. J. (1971). Trends in taxation in developing countries. Staff Papers, 18(2), 254-331.

Gupta, S.A. (2007). Determinants of Tax Revenue Efforts in Developing Countries. Washington D.C: IMF Working Paper.

Islam, M.A. (1979). Tax Effort in Bangladesh: Some Empirical Observation. journal of Bangladesh Development Studies, Vol. 7, pp.83-92.

Kenya National Bureau of Statistics. (2015). Economic survey. Nairobi: Government Printer.

Leuthold, J.H. (1991). Tax Shares in Developing Economies: A Panel Study, Journal of Development Economics, 35: 173-85.

Lotz, J. R., \& Morss, E. R. (1967). Measuring "tax effort" in developing countries. Staff Papers, 14(3), 478-499.

Lutfunnahar, B. (2007). A Panel Study on Tax Effort and Tax Buoyancy with Special Reference to Bangladesh. Working Paper 715: Policy Analysis Unit (PAU) Research Department Bangladesh Bank

Mahdavi, S. (2008). The Level and Composition of Tax Revenue in Developing Countries: Evidence from unbalanced panel data. International review of Economics and Finance, 17,607-617

Muriithi, M.K. and Moyi, E.D. (2003). Tax Reforms and Revenue Mobilization in Kenya. AERC Research Paper 131, Nairobi: AERC. Paper 107: International Monetary Fund, Washington, DC

National Treasury. (2016). Budget statement for financial year 2016/2017: Consolidating gains for a prosperous Kenya. Nairobi: Government Printer.

Pessino, C. and Fenochietto, R. (2010). Determining Countries' tax effort. Washingon D.C: IMF Publication.

Republic of Kenya (2010). The Constitution of Kenya, Nairobi: Government Printer.

Stotsky, J.G. and Wolde Mariam, A. (1997). Tax Effort in Sub-Saharan Africa. Working Paper 107: International Monetary Fund, Washington, DC. Tanzi,V.(1992). Structural Factors and Tax Revenue in Developing Countries: A Decade of evidence in Open Economies. Cambridge: Cambridge University Press. 
Teera, J. M.(2002). Determinants of tax revenue shares in Uganda. University of Bath, Department of Economics, United Kingdom.

Wawire, N. H. (2000). Revenue Productivity Implications of Kenya's Tax System. Africa in transformation. Political and economic issues, 1, 99-106.

Wilford, D. S., \& Wilford, W. T. (1978). On Revenue Performance and Revenue-Income Stability in the Third World. Economic Development and Cultural Change, 26(3), 505-523.. 